\title{
ON ORGANIZING EDUCATIONAL ACTIVITY OF THE FUTURE TEACHING COACHES
}

\begin{abstract}
In didactics of higher education institution's scientists reveal the forms of learning process organisation and the forms of teaching students through the ways of the interaction between the teacher and their students when solving didactic tasks. They are revealed by means of different ways of activity management, communication, interpersonal relations. The content of education, educational technologies, styles, principles, methods and teaching aids etc. are realized in them. The analysis of the Ukrainian studies and publications of the decade (A. M. Aleksyuk, Y. Y. Bolyubash, A. A. Vasilyuk, V. I. Bondar, V. A. Semichenko and others) gives reasons to state that unfortunately we observe the substitution of two notions: the form of organization and the form of teaching, as well as narrowing the notion "teaching of students".
\end{abstract}

Keywords: forms of teaching, the form of organization, forms of organization of teaching

\section{INTRODUCTION}

A lot of scientists unintentionally avoid this question and content themselves with an ordinary notion about the essence of the given category. Scientifically the term "form" is considered both from the linguistical and philosophical point of view. Dictionaries define the term "form" as "external look, exterior, outline of a subject"; "...The form is the internal organisation of the content... The form reflects the system of the stable relationships of the subject". Didactics of the higher school defines "form" as a special structure of the learning process the nature of which is conditioned by content, methods, techniques, aids and types of students' activity. Being the external view of teaching cycles, the form also reflects the system of the stable relations between the components within each teaching cycle and depends on the quantity of students (individual, individual and group learning, collective or frontal), place of teaching (work in class or unassisted work), the procedure of classes etc. Thus, the form of teaching as a didactic category means the outer side of teaching process organisation which is connected with the quantity of students, time and place of teaching, as well as its procedure. The scientists following the classical terminology single out two notions: "the form of teaching" and "form of organization of teaching/learning" (Махмутов, 1985). We must admit that regarding teaching/learning of students the term "form" is used also in two versions: as the form of teaching/learning and as the form of organization of teaching/learning. The term "organization" philosiphically is defined as ordering, adjustment in the system of certain material or spiritual object, location, correlation of parts of the object (Философский энциклопедический словарь, 1997).

\section{THE AIM OF THE STUDY}

To research and categorize various forms of organization of teaching/learning process of future teaching coaches at higher education institution. 


\section{MATERIALS AND METHODS}

Within the context of this study the definition teaching/learning "forms of organization of teaching" as a certain structural, organisational and managing pattern of classes depending on didactic purposes, content, quantity of students and peculiarities of activity of subjects and objects of teaching. The forms of organization of teaching/learning must streamline the educational process. Didactic purposes are their main criterion of categorization, each form of organisation may have several didactic purposes. The forms of organization of teaching/learning which we call specific are divided into individual, group and frontal. The basis for the classification of the specific forms of teaching/learning are characteristic features of the peculiarities of the communication interaction between a teacher and students, as well as between students themselves. The individual forms of teaching/learning of the future teaching coaches presupposes the interaction of the teacher with one or several students ( $7 \pm 2$ or J. Miller's rule). The group organization of the form of teaching/learning is realized in a group of students, which is created according to different criteria (the level of the cognitive development, gender etc.). The frontal organization of the form of teaching/learning of the future teaching coaches enables to organize the work with the whole group of students at unified pace and with common tasks. Let's define our position that the form of organization of the instructing of future teaching coaches is a purposeful, rich in content and methodically equipped system of cognitive and educational communication, interaction, relations between a teacher and their students. The forms of organization of students at lessons can be different and depend on a number of circumstances: the quantity of students present at the lesson; the place where the lesson is held: in the auditorium, laboratory, cabinet classroom, pool etc.; the arrangement of students: at desks, in a semicircle, face to face with each other etc; the organization of activity. Consequently, changing form of organization of educational process naturally influences psychological features of participants of the learning process (Поляков, 2006, 98) The forms of organization can be described using several criteria among which important are: time limitation (determined time limits of the learning process) - flexibility (the beginning and finishing of learning situation has not an exact time border); monolithic nature (the internal unity of the lesson - the subject); fragmentariness (fragmentation of the lesson into relatively completed parts); spatial features - locating particularities of the participants of interaction.

The researchers proved that by successive varying ways of the desk and chair arrangement in the auditorium one can change the location of students during the learning process and, thus, trace changes of the nature of their learning activity (Растянников, 2002, 8). In modern social psychology spatial regulation of human behaviour is one of popular research and practical problems. There appeared even a science about human behaviour in area of direct communication, proxemics, but (its) achievements are meanwhile little claimed by psychology and educational practice (Савенков, 2006). The problems of the study of particularities of the human territorial behaviour and their private psychological domain are closely connected with the problems of assisted learning activity. Learning activity proceeds mainly as general, however consideration of this aspect requires giving more precise definitions.

When future teaching coaches learn together their private psychological domains actively contact and even cross each other, probably, there appear areas of mutual overlay in these domains. Thus, to teach someone something one has to break in their private domain. When learning, a person stays a social being, and mechanisms of social interaction essentially determine both the nature of learning process and its result. Obviously, presence of other people during studying switches on some important mechanisms, intensifies learning process, 
these mechanisms are not to be switched off but should be actively used (Растянников, 2002, 8). The domain is an area or space which people regard as their private, it is supposedly the continuation of their bodies. Every person has their own private domain. The air space of a person ("air chamber") depends on the population density, where the person grew up; it is defined by the cultural environment, social status etc. The research established that the radius of the air space around a middle class person of the developed civilized countries is practically the same. It can be divided into four main zones: intimate zone (from 15 to $45 \mathrm{~cm}$ ), private zone (from $46 \mathrm{~cm}$ to 1,22 m), social zone (from 1,22 to 3,6 m), public zone (over 3, $6 \mathrm{~m}$ ). Thus, using uncomfortable and small rooms as auditoriums for education of the future teaching coaches is a violation of psychological domain of a student (according to sanitary and hygienic norms the distance from the first desk to the blackboard should be no less than $240 \mathrm{~cm}$ ). It is well known that in terms of ergonomics auditoriums of the amphitheatre type, with stable furniture and minimum or even absence of windows, are the most comfortable for lectures. For seminars more suitable are auditoriums with flat floor and with movable furniture. The private psychological domain is a student personality resource. Particularly for introverts who get tired quickly enough, exhausts while communicating, in active interaction, and that is why hurries to find a place to stay alone to restore internal energy, come to balance, be harmonized, newly feel themselves. Introverts vitally need such domain, but it is needless to think that extroverts don't require one. An extrovert student needs psychological private domain to bring their thoughts, impressions, emotions in order.

In specialized psychological studies it was repeatedly noted that the presence of other people itself during carrying out certain individual activity influences its final result (Растянников, 2002, 5). In the opinion of A. I. Savenkov (Савенков, 2006), in this case individual activity already may be considered common. Functioning of this mechanism is defined by means of special term "social facilitation". The phenomenon characterizes the influence of other people presence on the actions of the individual. Certainly, using definition "social facilitation", specialists imply certain consequences caused by presence of other people regardless of their activity intensity. Common activity is usually treated as one carried out by different people to make some common single product. Such activity is seldom found in classical education more often we deal with the individual activity running in other people presence (Растянников, 2002). Special place in psychological studies of assisted activity is occupied by the problem of the correlation of efficiency of individual and group activity. Most scientists note that group action, as a rule, qualitatively and quantitatively exeeds the one of the average individual, but quite often yields in efficiency to the action of an individual (Савенков, 2006; Шмерлина, 2003; Шендрик, 2003). As we see, assisted activity is an efficient instrument, but it can be used with degrees of effectiveness. Anyway one can note that its educational potential to a significant extent is unknown and is used by higher educational institutions not in full. Teaching/ learning of student can occur only then, when it is somehow organized, it occurs and exists first of all in certain forms of its organization. The organizing teaching/learning forms constitute the material base of education. The forms of teaching/learning process organization of future teaching coaches which we analysed are most reasonable forms when taking into account private psychological domain. The forms of teaching/learning organization are an external expression of mutual activity of students and teachers. It's worth noticing that this notion has no stable unambiguous definition. We should define that the form of teaching/learning organization is a mutual activity of the teacher and the students which is realized in a determined way and fixed 
schedule. Teaching of students cannot be realized beyond some organizing form because it is a purposeful organization of communication in the process of interaction between the teacher and the students, it is characterized by distribution of organizing functions, selection and the sequence of links of instructional work, schedule - temporary and spatial.

There exist empirical grounds confirming that interaction between students and interpersonal relations caused by these interactions are only a comparatively independent instant of the development mutual activity between the teacher and students. Just in the system of the interaction between the teacher and the students the basis is made for new value orientations, semantic sets and social expectations which are not always consciously realized in the system of the interaction between students themselves when assisted solving educational tasks. The interactions in the system "teacher - student" provide continuity of the forms of teaching/learning interaction and produce the basis for development of the variety of these forms. The study of mutual activity between the teacher the students in a number of experimental research allows to reveal the general peculiarities of the specified interaction. First of all, interaction between the teacher and students act as a necessary side of organization of the whole system of training situations. Producing any new activity turns out to be impossible beyond thorough cooperation acts between the teacher and the students.

When executing experimental work both traditional (passive, reproductive) and active were used, as well as interactive methods of teaching future coaches. The passive method is a form of the interaction between the teacher and the students when the teacher is a main figure of the educational activity (lectures, seminars etc.), and students play the role of passive listeners. To advantages of such form of interaction we can attribute: possibility to give a large amount of teaching material; comparatively uncomplicated preparation to classes; employment of students (put down lecture notes), silence at lectures, but there are disadvantages: students play the role of passive listeners: disinterestedness (in most cases), lack of attention, few types of activities at the lesson, the most inefficient way, from the point of view of students, of teaching material assimilation, as a rule, authoritarian style of teaching.

To active methods of teaching of the future teaching coaches we put such form of the interaction between students and a teacher, when they interact with each other in the course of a lesson, and students act not as passive listeners but as active participants of the lesson. The teacher and students are main participants of the lesson. The advantages are the interaction between students and the teacher, students are active participants of the lesson and democratic style of teaching is promoted. However there still are disadvantages: little creative activities at the lesson, teachers themselves direct student to certain conclusions.

Interactive ("inter" - mutual, "act" - act) means to interact or communicate with somebody. In other words, interactive methods of instructing future teaching coaches is a special form of organization of cognitive, practical and communicative activity, in the course of which students turn out to be involved in the process of learning, have a possibility to understand and reflex about what they know and consider. The role of the teacher in interactive lessons lies most often in directing students' activity to achieving the goals of the lesson. He/she makes out the plan of the lesson (as a rule, it is a collection of interactive exercises and tasks, working with which a student studies the material). Thus, the basic components of interactive lessons are interactive exercises and tasks done by students. The principle difference between interactive exercises and tasks from ordinary ones lies in the fact that in the course of their completion not only already studied material is revised but the new material is learned. 
Let's name separate positions and rules of the division of future teaching coaches into subgroups.

Student division into subgroups is necessary only when the need arises. For teaching/ learning to be successful, it is necessary to use individual and group forms of activity. It means that the teacher must plan heterogeneous activity in groups: a student individually works on a practical task or situation; the student works in assistance with others; the student chooses or the teacher indicates the group, with which the student will work (the groups are created on the grounds of needs and abilities of every student). In author's opinion, it is reasonable to mention here also the forms of cooperation offered by the Australian researcher Penny Ur (1996).

Now the rules of preparing student to working in groups will be described.

1. To define what students must learn? It is necessary clearly to define what knowledge, skills and experience students must acquire due to work in groups. What are the goals? Why does the teacher want them to learn this? How much time will it take them to achieve the goals?

2. What is it necessary to take into account when planning? a) Time. The best model is to start with the explanation of the task to all students, then goes a group work and results with the participation of all students; b) Place. Group work requires changing the place of the lesson. The teacher must take into account what the groups are doing; the students can walk in auditoriums; the members of the group must see and hear each other; all aids must be available; c) Materials. The tasks will be more interesting if you ask them to use their different aids. You should check what is available and use it, study individual (exercise-books) sheets for each student, take into account age and individual peculiarities d) Instructions. They define whether the group understands the task and ways its execution. The instructions can be offered on cards with tasks or in many copies; they must be clear and detailed so that the group could execute them by means of, with partial help or without help of the teacher; the results must be clearly outlined (the specimen is given) and are checked in practice (do it yourself); e) Skills to work in groups. It is quite possible that the teacher will have to devote much time to teach students the bases of cooperation in groups.

3. The cooperation bases: what are the ways the students should behave? The duties of the members of the group: listen to their companions, ask for help; to help if someone asked about it.

4. How to divide students into groups? For short tasks it's best to make groups of 4-5 students. The greater groups can be required for long-term tasks if the tasks are divided into stages). The groups must be different (considering the level of students, sex etc.). The teacher can choose the group for a student. Students can choose the group on the grounds of their interests, if groups do different tasks (Дитиняк, 2003, 34-38).

5. How to teach to treat other constructively? At the end of the lesson it's necessary to discuss with the students what new experience they have gained, what are the results of the work etc.

6. How to carry out some work in groups? Before the lesson one should prepare the materials, arrange the tables and chairs in accordance with the plan for the lesson. Briefly discuss with the students the subject of the lesson. Divide the students into groups. Define the tasks, handing out materials. Give the groups time for acquaintance with tasks. Make sure that everyone understood the instructions. Define time for execution. Ask one member of the group to declare the results of the work. Discuss the results with all the students. 
7. What to do while students are working? When students are working in groups, teacher is an observer supporter. He can help the students who work in groups, asking them what is already done and help offering open-ended questions (Дитиняк, 2003, 34-38). Using offered forms of mutual activity, in the way of the experimental work with future teaching coaches, we advanced different forms of the interaction and communication aimed at individual creative development of each student and that is as much important, of the teachers themselves.

\section{RESULTS AND CONCLUSIONS}

Thus, matching forms of the interaction (Ляудис, 1980) and modes of work stated by the author, it is possible to define the following forms of mutual activity of the teacher which can be introduced into learning process: 1) introduction into activity - it is realized as frontal questioning where the teacher is a dominant figure, as well as the activity, with the teacher in the highlight. For instance, when giving lecture, mini-lecture, seminars. In this case students only perceive information; 2) divided action is realized as the individual work, the teacher provides help and control; 3) imitated action - to this category we can put working in pairs when students play certain roles approbating elements of professional activity, as well as imitating when a student gets the possibility of execution the functions of the teacher; 4) supported action - it is effectively realized through teamwork. The role of the teacher is a role of the listener, arbitrator and leader. Also this form of the interaction can be realized by means of cooperation - students execute the same tasks, as by the individual work but they work in pairs, sets of three; 5) self-regulating action - it runs in the way of self-organization when students choose the learning task themselves and execute it autonomously; 6) partnership - in the same way as the supported action it can be realized on principle of cooperation but with use of elements of self-regulating actions.

It is well-known that practical activity of the teacher is always richer than theory; therefore there is a great number of possible variants of mutual activity that helps to understand the cooperation between the teacher and the students as a natural process which has an internal psychological tension. The realization of the education of future teaching coaches requires knowledge and skilful use of the various forms of organization in the teaching/learning process of higher educational institution, their constant improvement.

\section{REFERENCES}

Penny, Ur. (1996). A course in language teaching. Practice and theory. Cambridge, Australia: Cambridge University Press, pp. 109-149.

Дитиняк, Г. Я. (2003). Досліджую, експериментую, спостерігаю. Г. Дитиняк, Л. Андрушко, Н. Древня (Eds.). Львів: Літопис, 140 с.

Махмутов, М. И. (1985). Современный урок. Москва, 49 с.

Поляков, С. Д. (2006). Как управлять психологией урока, или Психопедагогика в образовании. С. Д. Поляков, С. В. Данилов, М. В. Ерхова, И. А. Семенова (Eds). Москва, 160 с.

Растянников, А. В. (2002). Рефлексивное развитие компетентности в совместном творчестве. А. В. Растянников, С. Ю. Степанов, Д. В. Ушаков (Eds.). Москва: МГПИ, с. 23-123.

Савенков, А. И. (2006). Расстановка парт и психологическое пространство учащегося в классе. Директор школь, № 8, с. 44-56.

Философский энщиклопедический словарь. (1997). Москва: ИНФРА-М, 576 с. 
Шендрик, И. Г. (2003). Образовательное пространство субъекта и его проектирование. И. Г. Шендрик (Еd.). Москва: АПКиПРО, 452 с.

Шмерлина, И. А. (2003). Междисциплинарные ракурсы социологии пространства. В Вестник РУДН (Серия “Социология”), № 1 (4), с. 53-66.

Ляудис, В. Я. (1980). Структура продуктивного учебного взаимодействия. В Психолого-педагогические проблемьв взаимодействия учителя и учащихся. А. А. Бодалева, В. Я. Ляудиса (Eds.). Москва: НИИОП АПН СССР, с. 37-52.

Associate Professor Andrey Vyacheslavovich Svatyev

Head of the Department of Olympic and professional sport, candidate of pedagogical Sciences

Zaporizhzhya National University, Ukraine

Phone mobile: +38-067-901-81-11

Phone home: 8 -10-380-0612-345229

E-mail:29011973@ukr.net 